ROCZNIKI PEDAGOGICZNE

Tom 11(47), numer specjalny -2019

DOI: http://dx.doi.org/10.18290/rped.2019.11s-15

ANNA KIESZKOWSKA

\title{
MOŻLIWOŚCI PRACY Z OSOBAMI WYKLUCZONYMI SPOŁECZNIE W INKLUZYJNO-KATALAKTYCZNYM MODELU W PROCESIE REINTEGRACJI SPOŁECZNEJ
}

Obecnie we współczesnym świecie obserwuje się w zjawisko zobojętnienia, zmęczenia, znużenia, niezadowolenia, osamotnienia i wycofania. Coraz większa anonimowość powoduje, że los innych staje się mało istotny, a niska wrażliwość społeczna zagłusza w społeczeństwie potrzebę współbycia, współżycia i współdziałania na rzecz innych.

Podejmowanie przez pedagogów działań dotyczących stymulacji wewnętrznych warunków wzrostu i przeciwdziałania zanikowi rozwijającej się integracji społecznej w obrębie środowisk lokalnych może być uznane za pewną próbę oczekiwanej i prowadzonej w tej dziedzinie kompensacji. Analizując problem aktywności występujący na terenie społeczności lokalnych, należy uwzględnić zarówno tendencje dynamiczne tkwiące w samej jednostce, mobilizujące ją do działania, jak i konkretne społeczne i historyczne warunki, w których funkcjonują ludzie, ich systemy wartości, role społeczne i światopoglądy.

\section{CZŁOWIEK W SYTUACJI ZAGROŻENIA} WYKLUCZENIEM SPOŁECZNYM LUB MARGINALIZOWANIA

Interakcje zachodzące w systemie społecznym mają istotne znaczenie dla dojrzałego i odpowiedzialnego funkcjonowania człowieka w wymiarze biologicznym, psychologicznym i cywilizacyjno-kulturowym (tabela 1).

Dr hab. Anna KieszKowska - prof. UJK - Uniwersytet Jana Kochanowskiego, Instytut Pedagogiki i Psychologii, ul. Krakowska 11, 25-029 Kielce; e-mail: annakieszkowska@ ujk. edu.pl; ORCID: 0000-0003-2601-1595 
Tabela 1. System społeczny, jego podsystemy i funkcje

\begin{tabular}{|c|c|c|c|c|c|}
\hline $\begin{array}{c}\text { Systemy } \\
\text { Podsystemy }\end{array}$ & Funkcje & $\begin{array}{l}\text { Elementy } \\
\text { struktury }\end{array}$ & $\begin{array}{c}\text { Zespoly } \\
\text { strukturalno- } \\
\text {-funkcjonalne }\end{array}$ & \multicolumn{2}{|c|}{$\begin{array}{c}\text { Porządek } \\
\text { informacyjno- } \\
\text {-energetyczny }\end{array}$} \\
\hline Kultura & $\begin{array}{c}\text { Stabilność } \\
\text { normatywna }\end{array}$ & $\begin{array}{l}\text { Wartości } \\
\text { Wzory } \\
\text { kulturowe }\end{array}$ & $\begin{array}{l}\text { Socjalizacja } \\
\text { Edukacja } \\
\text { Resocjalizacja } \\
\text { Readaptacja }\end{array}$ & \multicolumn{2}{|c|}{+ nasycenie -} \\
\hline Społeczeństwo & $\begin{array}{l}\text { Integracja } \\
\text { społeczna }\end{array}$ & $\begin{array}{l}\text { Normy } \\
\text { Nakazy }\end{array}$ & $\begin{array}{c}\text { Prawo } \\
\text { Moralność } \\
\text { Obyczaj }\end{array}$ & \multirow{2}{*}{ 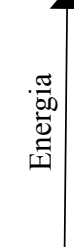 } & \multirow{2}{*}{ 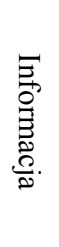 } \\
\hline Osobowość & $\begin{array}{c}\text { Realizacja celów } \\
\text { jednostki }\end{array}$ & $\begin{array}{l}\text { Realizacja } \\
\text { celów grupy }\end{array}$ & $\begin{array}{l}\text { Polityka globalna } \\
\text { Realizacja celów } \\
\text { makrospołecznych }\end{array}$ & & \\
\hline Organizm & $\begin{array}{l}\text { Adaptacja } \\
\text { Akomodacja } \\
\text { Asymilacja }\end{array}$ & $\begin{array}{l}\text { Role społeczne } \\
\text { i postawy }\end{array}$ & $\begin{array}{c}\text { Ekonomia } \\
\text { Gospodarka } \\
\text { Infrastruktura }\end{array}$ & \multicolumn{2}{|c|}{- nasycenie +} \\
\hline
\end{tabular}

Źródło: L. Pytka (2010). Readaptacja jako element polityki reintegracji społecznej, s. 21.

Zamieszczony schemat ujmuje człowieka i jego świat w kategoriach systemowych jako sprzężone ze sobą układy struktur i funkcji. Zmiana jednego z elementów struktury lub funkcji pociąga za sobą szereg innych zmian, trudnych do przewidzenia. Gdy pojawiają się sytuacje trudne, zaburzenia, odchylenia od normy czy dysfunkcje, to zachwiania patologiczne rozpoczynają się na poziomie biologicznym, przechodzą przez poziom psychologiczny, społeczny i zatrzymują się na poziomie kultury, owocując patologiami w szerszym i bardziej niebezpiecznym wymiarze. Tu następuje adaptacja, czyli dostosowanie się do pełnienia określonej roli i panujących reguł oraz kształtowanie określonej postawy w stosunku do siebie, bliskich i środowiska, a także zachodzących zjawisk społecznych w określonym czasie (Pytka, 2010). Utrzymanie prawidłowego metabolizmu informacyjno-energetycznego między systemami gwarantuje sprawne funkcjonowanie całości, sprzyja rozwojowi całego systemu i jest źródłem jego sprawności i skuteczności. Człowiek odpowiada w pełni za swoje działania i podejmuje nowe wyzwania.

Drugi poziom funkcjonowania człowieka wiąże się z kształtowaniem struktur poznawczych, emocjonalnych, behawioralnych i przyswajaniem treści społeczno-kulturowych z najbliższego otoczenia. To czas szczególny dla człowieka, bowiem następuje tu realizacja ważnych celów życiowych jednostki i grupy (formalne i nieformalne), uwzględnianie interesu własnego i innych, realizacja celów grupy (zaangażowanie, poświęcenie, rezygnacja, wycofanie), poznawanie 
strategii polityki państwa na rzecz jednostki, rodziny, pomocy socjalnej czy woluntarystycznej wobec grup społecznych. Wrastanie w określoną grupę społeczną, przynależność do niej, poznawanie i określanie własnej tożsamości stanowią podstawę do dalszych działań życiowych i pełnienia określonego miejsca w społeczeństwie (Kieszkowska, 2012, s. 26).

Poziom trzeci (społeczeństwo) określa zorientowanie na cele społeczne, na podejście ,ja”, „my”, ale też w wymiarze „oni-inni”, „,nasz-obcy” czy „,lepszy-gorszy". Podstawowa funkcja systemu wyraża się w zainicjowaniu i podtrzymaniu stabilności normatywnej całego systemu poprzez procesy socjalizacyjne, edukacyjne, skłaniające do internalizacji norm obyczajowych, moralnych i prawnych oraz ważności wartości w życiu. Na tym etapie wyłania się człowiek, dobrze lub źle zsocjalizowany, wychowany, ukształtowany, zdolny do podejmowania w sposób odpowiedzialny określonych ról społecznych i mający właściwe podejście do wykonywania zadań oraz poczucie odpowiedzialności za swój los, rodziny i bliskich, a także - w przypadku negatywnych czynów - za ofiary przestępstwa, z czym wiąże się przeżywanie wyrzutów sumienia i dążenie do złagodzenia tego stanu, lub też wadliwie zsocjalizowany, przejawiający zachowania aspołeczne, antyspołeczne, neurotyczne czy zachowania nadwrażliwe. Ma tu zastosowanie aktywna polityka społeczna, obejmująca zagadnienia edukacyjne, reedukacyjne, integracyjne i reintegracyjne, ekskluzyjne i inkluzyjne jednostki i grupy w systemie społecznym. Ważne na tym etapie będą wzory zachowań społecznych przejawiane przez określone grupy społeczne oraz najbliższe otoczenie danej jednostki, jej własne doświadczenia zdobyte w kontakcie indywidualnym i zbiorowym na temat reguł postępowania społecznego, a także infrastruktura danego środowiska stwarzająca określone warunki sprzyjające wszechstronnemu rozwojowi w miejscu zamieszkania i szanse realizacji ról społecznych i zawodowych. Człowiek doświadcza wydarzeń i emocji w sposób bardzo indywidualny, dzięki czemu staje się jedyny w swoim rodzaju i wyjątkowy, ponieważ posiada unikalne wewnętrzne doświadczenia emocjonalne (Benson, 2001).

Ową indywidualność w znacznym stopniu determinuje proces socjalizacji, rozumianej jako

proces umożliwiający jednostce zaistnienie społeczne, czy zamanifestowanie biologicznej gotowości i możliwości stawania się i bycia istotą społeczną przeżywającą swoje biograficzne życie w jakiejś typowej formie uczestnictwa społecznego bądź konstruujące $\mathrm{w}$ danym układzie społecznym sekwencje następujących po sobie różnych tegoż uczestnictwa tworzących standardową względnie niestandardową ich postać w społecznej biografii: odpowiadającej pielęgnowanym w kulturze 
danego układu społecznego wartościom i wzorom ich chronienia bądź zdystansowania wobec tych wartości i wzorów, bądź zagrażającą im i układowi ich kreacji (Modrzewski, 2004, s. 14).

Równolegle z trwającym przez całe życie procesem socjalizacji jednostka rozwija się i kształtuje kompetencje do działania oraz formułuje własną tożsamość. Zdaniem K. Hurrelmanna (1994) środowisko społeczne i materialne jest w pierwszej kolejności przez człowieka doświadczane zmysłowo, a dopiero w następnej kolejności jest przez niego porządkowane w taki sposób, aby ostatecznie zostało zrównoważone z jego osobistymi potrzebami, planami i emocjami. Każda konfrontacja z rzeczywistością zmienia te środki, uzdolnienia, prowadząc jednocześnie do ich rozwoju, służąc realizacji własnych predyspozycji oraz przetwarzaniu rzeczywistości. Pracując nad sobą, jednostka musi zostać wyposażona w podstawowe zdolności w sferach sensorycznej, motorycznej, poznawczej i emocjonalnej oraz interakcyjnej, które pomagają przetwarzać środowisko. Proces konfrontacji i przyswajania sobie wewnętrznej i zewnętrznej rzeczywistości - zdaniem autora - trwa przez cale życie, a jego sprawność osiągana jest $\mathrm{w}$ toku rozwoju rzeczywistości.

Z kolei D.P. Farrington (1992) twierdzi, że motywacje i uwewnętrznione postawy są współodpowiedzialne za łamanie norm społecznych i popełnianie przestępstw. Jednostka dokonuje przestępstw w wyniku interakcji ze społeczeństwem. Poza aspołecznymi tendencjami na fakt dokonania przestępstw mają wpływ również czynniki zależne od sytuacji (nuda, frustracja, negatywne wzorce rodzinne czy środowiskowe, alkoholizm, narkomania, bezrobocie) oraz brak środków do życia (Shneider, 1997-1998, s. 32). Skłonność do popełniania przestępstw wzrasta w otoczeniu społecznym, w którym jednostka uczy się przestępczości i znajduje uznanie.

Według H.J. Shneidera (1997-1998, s. 32)

[...] czynnikiem mającym największy wpływ na wyrobienie u nieletniego więzi ze społeczeństwem i na to, aby nie zszedł na drogę przestępczości, jest rodzina, z której pochodzi. $Z$ wiekiem największy wpływ na zachowanie przyjmuje świat przyjaciół, szkoła i podkultura młodzieżowa. Kiedy zaś wkracza w wiek dorosły, możliwość stworzenia na nowo więzi ze społeczeństwem otwiera zaangażowanie w aprobowane działania, obowiązki podejmowane wobec nowo założonej rodziny.

Warto zauważyć, że elementy tych procesów są ze sobą powiązane pozycją, jaką zajmuje jednostka w strukturze społecznej. Proces przyczynowy jest dynamiczny i rozwija się przez cale życie, dlatego na początku więzi społeczne 
są słabe i mogą prowadzić do zaangażowania się w przestępczość, co z kolei wpływa na ich osłabienie. Kombinacja tych oddziaływań sprawia, że odbudowanie tych więzi w latach późniejszych jest bardzo trudne, co skutkuje brakiem dobrych relacji byłych więźniów ze społeczeństwem.

S. Kowalski (1977) zakłada, że predyspozycje do zachowań dewiacyjnych wynikają z niewłaściwego (asocjacyjnego) procesu socjalizacji przede wszystkim w środowisku rodzinnym, szkolnym i w grupie rówieśniczej. D.P. Farrington z kolei dodaje, że wpływ na popełnianie przestępstw ma bezpośrednia interakcja jednostki o aspołecznych tendencjach z otoczeniem, a także sytuacja i okoliczności życiowe związane bezpośrednio z jej funkcjonowaniem (konflikty, utrata pracy, bezrobocie, nadużywanie alkoholu czy narkotyków). Na znaczenie nieformalnych więzi społecznych oraz związków ze społeczeństwem w każdym okresie życia człowieka zwracają uwagę R.J. Sampson i L.J. Laub (1993) podkreślając, że społeczny związek z nieformalnymi instytucjami kontroli społecznej, takimi jak rodzina, społeczność lokalna, zakład pracy, ma wpływ na zachowania przestępcze na drodze życiowej, bez związku z przestępczą czy antyspołeczną przeszłością. Instytucje te kreują w rzeczywistości nieformalną kontrolę społeczną, która będąc odpowiednio mocna, może zapobiegać przestępczości, gdy natomiast jest słaba, może być przyczyną zachowań dewiacyjnych. Jedną z barier stojących na przeszkodzie samodzielnego rozwiązywania problemów przez społeczność lokalną jest jej bierność (Rylke, 2002) i zobojętnienie na problemy innych, stanowiąca przyzwolenie do rozwijania się zachowań ryzykownych w grupach społecznych.

Czwarty poziom, określony jako kultura, tworzy grupy i społeczności ze względu na przyjęte treści i wzory kulturowe, przekazywane w procesach socjalizacyjnych i edukacyjnych. Podstawową funkcją kultury lub podkultury jest zapewnienie „stabilności normatywnej” w społeczności, co przejawia się w posiadaniu określonych symboli, światopoglądu, wzorów kulturowych, preferowanych wartości, deklarowanych i uznawanych w grupie i społeczeństwie oraz realizowanych na poszczególnych poziomach istnienia i funkcjonowania jednostek, grup społecznych i państwa zarówno w środowisku życia, jak i w obrębie danej narodowości. W przypadku nasilenia symboliki czy światopoglądów niezgodnych z oczekiwaniami społecznymi dochodzi do konfliktów społecznych na tle politycznym, wyznaniowym, etnicznym (Pytka, 2012), a także często do wykorzystywania słabszych, sprawnych, inaczej do manipulowania ich zachowaniami i wprowadzania ich w konflikty z prawem.

Funkcjonowanie człowieka indywidualnego i społecznego nie byłoby możliwe bez przepływu energii oraz informacji między wyodrębnionymi poziomami, gdzie przepływ informacji odbywa się z góry do dołu, a przepływ energii z dołu 
do góry (tabela 1). Niedobory informacji, brak informacji, fałszywe i mało czytelne informacje zniekształcają i uniemożliwiają prawidłowe funkcjonowanie całego systemu, a poszczególne jednostki i grupy, często w sytuacjach trudnych, zagrożenia i niepewności, wymagają specjalistycznej pomocy ze strony profesjonalistów w obrębie systemu lub własnych członków rodziny.

Za zintegrowany można uznać ten system społeczny, w którym cele wyznaczane przez daną kulturę są w pełni akceptowane przez jednostki i osiągane za pomocą społecznie uznanych, zinstytucjonalizowanych środków z uwzględnieniem pracy określonych grup specjalistów. Wysoki poziom integracji społecznej charakteryzuje się intensywnością kontaktów między członkami danej zbiorowości, układem trwałych więzi społecznych spajających jednostki i grupy oraz ukształtowaną świadomością identyfikacji i łączności między nimi (Pytka, 2012).

Warto w tym miejscu zaznaczyć, że wszystkie programy profilaktyczne, readaptacyjne, reintegracyjne lub doskonalące funkcjonowanie systemu społecznego dla określonej grupy czy środowiska społecznego powinny wychodzić od najniższego poziomu, czyli konkretnych osób uwikłanych w problemy społeczne i społeczeństwa, aby zmienić ich sposób myślenia i wartościowania, wzajemnego funkcjonowania i uczestnictwa w danym systemie. Przejawem takiego uczestnictwa społecznego jednostki może być:

- sytuowanie się bądź kandydowanie osób społecznych do zajęcia określonego miejsca w strukturze społecznej. Zjawisko i proces społecznego uczestnictwa określają tu takie pojęcia, jak usytuowanie jednostki w przestrzeni społeczno-ekologicznej, zajmowanie przez nią pozycji społecznej, posiadanie lub nabywanie statusu społecznego, przynależenie do określonej grupy, społeczności, środowiska, układu społecznego;

- działanie przejawiane społecznie, właściwe dla danego układu społecznego, ze względu na który rozpatrywane jest uczestnictwo. Tu cechy świadczące o aktualizacji społecznego uczestnictwa wskazywane są poprzez opis funkcjonowania jednostki, odgrywania przez nią ról społecznych, występowania zachowań społecznych, wchodzenia w relacje z otoczeniem, więzi społeczne czy określone formy dialogu;

- ujawnienie posiadania lub wykształcenia się określonych cech psychospołecznych uznanych w nim za identyfikujące osoby go współtworzące i współokreślające kulturę. Do cech definiujących zjawisko i proces uczestnictwa społecznego zalicza się tu: świadomość społeczną, wiedzę społeczną, wyobraźnię społeczną, oczekiwania społeczne, tożsamość społeczną i cywilizacyjno-kulturową. Tak pojęte uczestnictwo może odnosić się do realnie istniejących 
osób i podejmujących określone role społeczne, realne pozycje i mających uznanie społeczne (Modrzewski, 2004).

Jak słusznie podkreśla J. Modrzewski (2004), należy rozważyć zagadnienie odniesienia uczestnictwa społecznego w danym układzie do osób co prawda istniejących realnie, lecz okresowo wyłączonych z danego układu lub przebywających w placówce penitencjarnej, uczestniczących w procesie readaptacji.

Uczestnictwo takich osób zarówno w okresie ich izolacji, jak i działania poza układem ich identyfikacji ma jedynie charakter przedmiotowy, ponieważ ich faktyczne istnienie nie ma znaczenia dla funkcjonowania społeczeństwa ze względu na obecność poza układem i ,pełnione role” w innym układzie. Taką rolę uczestnictwa w przypadku nieobecności mogą pełnić osoby realnie istniejące w środowisku, np. żony uwięzionych mężów, dziadkowie lub rodziny zastępcze, co w wielu przypadkach zaburza funkcjonowanie pozostałych osób. Role zastępcze pełnione przez żony lub mężów są najczęściej rolami podwójnymi. Zawsze istnieje ryzyko, że wystąpią pewne braki, niedociągnięcia i dysfunkcje w pełnieniu przyjętej dodatkowo roli, w szczególności w odniesieniu do małoletnich dzieci.

Jednostki stygmatyzowane, wykluczone ze społeczeństwa będą osobami, które ,utraciły właściwości, jakie umożliwiały im współprzyczynianie się do integracji danego układu, lecz uczestniczą w nim w dalszym ciągu podmiotowo, tworząc bądź współtworząc względnie izolowane w nim podukłady" (Modrzewski, 2004, s. 16), czyli obszary marginalizacji społecznej i instytucje nadzoru czy opieki, takie jak zakłady poprawcze, karne, domy opieki, schroniska. Przez to dochodzi do deprywacji społecznej, dyskwalifikacji, dyskryminacji, segregacji, degradacji czy stygmatyzacji tych osób w podejściu społeczeństwa i uznawanie ich za „odpadki społeczne”. Izolowanie tych osób nie wiąże się z całkowitym odrzuceniem z tego układu, bowiem po okresie wyznaczonym przez dany układ (pobyt w zakładzie karnym, hospitalizacja, banicja) jednostka ma możliwość powrotu.

W tym przypadku osoba nie traci właściwości przynależności do społeczeństwa, przygotowując się do powrotu do danego systemu, jednak istnieje możliwość zmiany swojego układu uczestnictwa i wejścia do innej grupy z posiadanymi zasobami i potencjałami. Dla pierwotnego układu staje się jednocześnie osobą nieistniejącą, dochodzi wtedy do tzw. śmierci społecznej. Wydaje się, że jednostka nie pozostaje sama, lecz przynależność do nowego układu może często wynikać z konieczności (np. przynależność do grupy bezdomnych). W takich sytuacjach można mówić o zróżnicowanym charakterze uczestnictwa społecznego w danym układzie, m.in. identyfikacyjnym, specjalizującym, adaptacyjnym, retrogresywnym, projekcyjnym czy ideacyjnym. Ze 
względu na omawianą problematykę osób przez jakiś czas pozostających poza systemem, a w procesie readaptacji przystosowujących się do funkcjonowania społecznego, wydaje się zasadne zwrócenie uwagi na typ retrogresywny uczestnictwa społecznego. Polega on na wycofaniu się jednostki z aktywnego udziału w danym układzie społecznym ze względu na zaistniałe okoliczności niemożności pełnienia ról $\mathrm{w}$ danym kręgu społecznym lub na znacznym ograniczeniu uczestnictwa jednostki z powodu realizacji swojej roli w sposób nieakceptowany społecznie w danym systemie (Kieszkowska, 2012, s. 30).

Istotą tego typu uczestnictwa jest społecznie dopuszczalne lub wymuszone wycofanie się osoby z pełnienia przez nią określonej roli w grupie społecznej na rzecz roli degradującej jej pozycję społeczną, mimo to jednostka zachowuje po części znamiona podmiotowości społecznej. W tym typie uczestnictwa osoba może dalej brać udział podmiotowo lub podmiotowo-przedmiotowo albo może być społecznie izolowana, co nie ma szczególnego znaczenia dla integracji danego systemu społecznego. Co więcej, mimo pełnienia określonych funkcji przez te osoby zdegradowane, nie jest przydatna dla systemu, zaś przekraczanie granic nie jest już zagrożone ostrymi sankcjami społecznymi (Kieszkowska, 2011). Dalsze uczestnictwo w życiu społecznym wiąże się ze względnie trwałą degradacją jednostki i jest efektem selekcji, która ma na celu eliminację z dalszego czynnego udziału w życiu społecznym.

\section{IDEA STRATEGII I KONCEPCJI REHABILITACJI SPOŁECZNEJ CZY OKREŚLONE DZIAŁANIA NA RZECZ INNYCH}

W pedagogice społecznej, resocjalizacyjnej i profilaktyce społecznej coraz częściej obserwuje się prowadzenie rzetelnej diagnozy wybranych obszarów, dostosowywanie działań do istniejących potrzeb, a także opracowywanie strategii i procedur działań profilaktycznych. Obecnie działania pedagogów, psychologów, pracowników socjalnych skupione są na rodzinach problemowych, określonych grupach ryzyka, osobach uzależnionych, chorych, niepełnosprawnych. W literaturze coraz częściej podkreśla się i wymienia określone wskaźniki, np. dla uzależnienia, bezrobocia, ubóstwa, bezdomności, wykluczenia ludzi opuszczających placówki penitencjarne, w tym starzejących się, i wielu innych zagrożeń, lecz stosunkowo mało uwagi poświęca się wskaźnikom pozytywnej readaptacji społecznej i integracji, a szczególnie poprawnej i udanej readaptacji osób, które w określonym czasie otrzymały należną pomoc i ponownie weszły w role społeczne w środowisku życia. 
Ze względu na rozmiary występowania wielu zagrożeń społeczeństwo winno mieć określone kompetencje, aby nie dopuścić do pogłębiania się zachowań patologicznych i wyzwalania zachowań stygmatyzujących. Dziś samo wykorzystanie strategii interwencyjnych wobec ogromu zjawisk patologicznych nie wystarczy, a zaangażowanie społeczne nie występuje z braku wewnętrznej potrzeby i przekonań społecznych. Występujące w literaturze i dokumentach urzędowych nowe określenia, zaczerpnięte z literatury anglojęzycznej, budzą zainteresowanie, czasem brak zrozumienia i oczekiwanie, że działania zapobiegawcze powinny być realizowane przez służby społeczne do tych celów powołane. Zastępowanie pojęcia „resocjalizacja” określeniem „reintegracja społeczna” czy - w pedagogice penitencjarnej - „readaptacją skazanych” ma wskazywać, że osadzeni nie tylko odbywają karę pozbawienia wolności, lecz są także poddawani edukacji, terapii i działaniom reintegracyjnym, aby w warunkach środowiska otwartego mogli w przyszłości samodzielnie funkcjonować i pełnić określone role społeczne razem z innymi, którzy są świadomi współuczestnictwa i współodpowiedzialności za losy tych drugich.

Fundamentalną ideą nowej strategii i koncepcji rehabilitacji społecznej staje się nadzieja na integrację osób ze społeczeństwem, postulat wartościowego ich uczestnictwa w życiu rodzinnym, sąsiedzkim, lokalnej społeczności, jako cel i metoda rehabilitacji jest drogą do zmiany ich rzeczywistego losu (utrata statusu społecznego, utrata zdolności do pracy, ograniczenie relacji i braku możliwości wchodzenia w role społeczne i zawodowe).

Nadrzędny cel integracji w społeczeństwie polega na zapobieganiu skłonnościom o charakterze izolacyjnym, braku akceptacji, segregacji, dyskryminacji czy nietolerancji wobec osób niepełnosprawnych nie znajdujących miejsca we współczesnej kulturze humanistycznej. Dla stworzenia odpowiednich warunków do budowania systemów norm i wartości, a także wspólnoty interesów w zwalczaniu życiowych problemów należy przede wszystkim kształtować pozytywne więzi społeczno-emocjonalne między osobami o różnym stopniu sprawności psychicznej, fizycznej i społecznej. Efektem tego będzie nowa jakość oraz zwiększenie częstości kontaktów na poziomie formalnym i nieformalnym dla określonych jednostek i grup społecznych. Ostateczny cel integracji sprowadza się więc do przygotowania osób dysfunkcyjnych do godnego życia i aktywnego uczestnictwa w podejmowaniu wszelkich ról społecznych (Dykcik, 2001). Integracja zakłada tworzenie kolektywnych poglądów, wartości, interesów czy dążeń, a jej istotę stanowi ich realizacja. Należy jednak podkreślić, że w przypadku integracji zakłada się występowanie różnic, aby nastąpiło osiągnięcie wspólnego celu, pomimo odmienności. To istotny zamysł względem integracji niepełnosprawnych i sprawnych członków społeczności, gdyż zamiast dzielić, 
mogą być przychylne w zdobywaniu wspólnych celów i rozumieć inność drugiego człowieka, podobnie w stosunku do osób karanych, wykazujących motywację do poprawy funkcjonowania. W tym przypadku proces integracji ma charakter obustronny, a więc obejmuje wszystkie jednostki, których zadaniem jest wzajemne poznanie, co najmniej częściowa akceptacja oraz dostrzeżenie sensu wspólnej pracy. W ostatnim czasie coraz częściej społeczeństwo wydaje się rozumieć znaczenie integracji w środowisku i zdecydowane odejście od systemu segregacyjnego. Działania społeczne i legislacyjne na rzecz osób niepełnosprawnych są przykładem, że korzyści w wymiarze indywidualnym, społecznym, moralnym odnoszą obie strony: osoby niepełnosprawne i społeczeństwo. Wypracowanie określonych form integracji społecznej wymagało czasu i zaangażowania wielu teoretyków i ludzi dobrej woli oraz kształtowania świadomości społecznej w tym zakresie, co może również stanowić dobry przykład dla procesu reintegracji grup wykluczonych społecznie, w tym skazanych, powracających ponownie do środowiska lokalnego lub mogących w warunkach tego środowiska odbywać zasłużoną karę poprzez wypełnianie określonych obowiązków nałożonych przez sąd wobec społeczeństwa i samego siebie. Według A. Hulka (1992, s. 78) integracja

[...] wyraża się w takim wzajemnym stosunku pełno- i niepełnosprawnych, w których respektowane są te same prawa [...] i w których stwarzane są dla obu grup identyczne warunki maksymalnego wszechstronnego rozwoju. Integracja pozwala osobie niepełnosprawnej być sobą wśród innych. Integracja w takim znaczeniu może mieć zastosowanie do wszystkich sfer życia jednostki niepełnosprawnej - życia rodzinnego, kształcenia ogólnego zawodowego, pracy, czasu wolnego, aktywności społecznej i politycznej.

Znajduje tu zastosowanie integracja kulturalna, dotycząca zgodności lub jej braku w przypadku wzorów kulturowych, które występują w danej społeczności, i wzorów alternatywnych, które są uznawane poprzez odłam danej społeczności bądź jej członków, np. w zakresie sposobu spędzania wolnego czasu, konsumpcji czy też stylu życia. Integracja normatywna wyznacza poziom zgodności między wartościami i normami, którymi kierują się członkowie danej grupy, a tymi przyjętymi w danej społeczności. Kolejnym typem jest integracja komunikacyjna, określająca stan i rodzaj intensywności relacji i kontaktów społecznych między członkami danej grupy czy społeczeństwa, oraz integracja funkcjonalna, wskazująca na poziom zależności w obrębie wzajemnej wymiany usług i świadczeń, które są rezultatem podziału pracy między danymi jednostkami (Landecker, Werner, 1951). 
Podstawą zaistnienia integracji jest komunikacja, łączność i wymiana informacji między jednostkami w grupie, jednostkami a instytucjami, a także między instytucjami i grupową władzą. Ogromne znaczenie ma wzajemne zrozumienie, akceptacja i dialog, poszanowanie różnorodności kulturowej, wspieranie jednostki i grupy w realizacji ich celów życiowych. Wyobcowanie jest konsekwencją niskiego poziomu komunikacji z resztą grupy.

Najbardziej widoczną oznaką dezintegracji jest wzrost przestępczości, jaki można zaobserwować w dużych aglomeracjach charakteryzujących się nasileniem ruchliwości, chociaż obecnie dają się zaobserwować negatywne zjawiska w każdym miejscu. Ta nadmierna ruchliwość nie służy integracji normatywnej, ponieważ przy częstych przemieszczeniach dużo trudniej jest przystosować się do norm i wzorów obowiązujących w danej grupie. Tak krótkotrwała przynależność zakłóca angażowanie się w grupowe życie, zatem sprzyja izolacji. Im bardziej złożona jest grupa, tym trudniej jest uzyskać ujednolicenie ludzkich zachowań, a także bliskość norm i wartości z akceptowanymi w grupie, gdyż wówczas instytucje grupowe nie potrafią efektywnie oddziaływać na zachowania pojedynczych jednostek. Ponadto elementem, jaki zagraża integracji społecznej, są konflikty ról. Ma to związek z deficytem możliwości przystosowania do obowiązujących wzorów zachowań, które cechują każdą z nich, która chce być aktywna społecznie. Ten wzajemny stosunek, uznanie praw i akceptacja człowieka są bardzo pożądane w przypadku osób wykluczonych, które są nadal członkami danego społeczeństwa. Tworzyć wspólne społeczeństwo, czyli nowy model współżycia, w którym wszyscy uznają prawa innych i są otwarci na wspólne obcowanie. Taki model jest trudny do realizacji ze względu na konieczność przeprowadzenia reorganizacji systemu resocjalizacji i reorganizacji społeczeństwa. Wydaje się, że korzystniejsze jest dopełnienie społeczeństwa osobami skazanymi w warunkach wolnościowych (mając na względzie czyn i aktualny stan zdrowia psychicznego), proces jednak jest o tyle trudny, że w dużej mierze powodzenie integracji środowiska ze skazanym będzie zależało od specjalistów pomocy społecznej, kurateli, policji oraz rodziny, a niekoniecznie od społeczeństwa. Z kolei odcięcie i separacja od kontaktów z normalnym życiem sprawia, że wytwarzają się dwa światy, które niewiele o sobie wiedzą w sensie pozytywnym i budują swoją tożsamość wokół zróżnicowania: „my-oni”, „,swoi-obcy”. Według pragmatystów idea integracji jest zbyt idealistyczna. Wskazują oni na negatywne skutki budowania społeczeństwa złożonego z ludzi różnorodnych, bo w tym przypadku osoby wykluczone nie wniosą niczego wartościowego, a jedynie osłabią jej charakter funkcjonowania. Trudno się z tym zgodzić, bowiem ilość zakładów karnych i szpitali psychiatrycznych $\mathrm{w}$ danym systemie nie wnosi również szans na 
poprawę funkcjonowania danej społeczności, a jedynie zwiększa koszty ekonomiczne i koszty lecznicze utrzymania tych placówek i realizowania procesu leczenia przez całe życie, co prowadzi do wyraźnej segregacji społeczeństwa. A przecież , [... [udzie są w zasadzie jednakowo dysponowani do odczuwania wartości, szczęścia i cierpienia... Moja krzywda równa się cudzej krzywdzie, mój zysk nie jest ważniejszy od cudzego" (Grzegorczyk, 1979, s. 131). Zatem czy żyć „obok siebie”, czy „razem ze sobą”, czy podejmować działania na rzecz drugiego człowieka? Integracja społeczna jest wyrazem demokratyzacji sposobu życia, wynikającym z przemian cywilizacyjnych i kulturowych, gdzie na każdym etapie życia jednostka ludzka, bez względu na stopień dysfunkcji czy zagrożeń społecznych, ma zagwarantowane naturalne środowisko niesegregacyjne. Integracja wyraża dążenie do stworzenia jednostkom w trudnej sytuacji możliwości do ponownego lub częściowego włączenia się do normalnego życia, dostępu do instytucji i wszelkich usług przewidzianych i dostępnych w kraju.

Celem reintegracji jest przeciwdziałanie tendencjom segregacyjnym, izolacyjnym, stygmatyzacji, dyskryminacji osób wykluczonych i stwarzanie im szans powrotu do społeczeństwa. Działania reintegracyjne, w tym również samopomocowe, mają na celu odbudowanie i podtrzymanie umiejętności uczestniczenia w życiu społeczności lokalnej i pełnieniu na nowo akceptowanych ról społecznych w miejscu pracy, zamieszkania lub pobytu. Kształtowanie pozytywnych więzi emocjonalno-społecznych między ludźmi o różnym stopniu sprawności intelektualnej, psychicznej czy fizycznej stanowi podstawę dla funkcjonowania wspólnoty na poziomie dojrzałości obywatelskiej, zdolnej do prezentowania interesów grupy w rozwiązywaniu trudnych problemów. Ostatecznym celem działań reintegracyjnych jest przygotowanie dzieci, młodzieży, dorosłych do aktywnego i godnego życia w społeczeństwie z osobami z grup ryzyka, w tym z osobami po opuszczeniu zakładu karnego. W reintegracji chodzi głównie o podmiotowe, integralne podejście do osoby ludzkiej, do jej cierpień i problemów, odrzucenia, bezdomności, do bezradności i bezbronności, gdzie jedynie pomoc pedagogów, psychologów, pracowników socjalnych inspirowanych myślą etyczną, aksjologiczną, teoretyczną może sprzyjać integralnemu działaniu (Pytka, 2012).

Reintegracja społeczna to włączenie osoby do społeczeństwa, które potrafi zaakceptować, zrozumieć i tworzyć określone warunki do funkcjonowania takich osób, aby z etycznego punktu widzenia zapewnić wolność wewnętrzną, prawo do wyboru, odpowiedzialność jednostki, prawo do zaciągania zobowiązań. Reintegracja stanowi więc ponowną integrację człowieka ze światem społeczności, następującą po okresie przeżyć traumatycznych, zachwiania psychicznego lub izolacji (Bałandynowicz, 2011). 
Wiesław Ambrozik (2010, s. 66) zadaje pytanie, w jakim stopniu społeczeństwo jest przygotowane do podejmowania działań i rozwiązywania problemów, aby przyjąć byłego przestępcę $\mathrm{w}$ ramach reintegracji społecznej do środowiska lokalnego. Najczęściej ludzie dystansują się w takiej sytuacji, a powstające w niewielkim zakresie systemy ,rzekomej pomocy i reintegracji społecznej nie reorganizują współczesnych społeczeństw ku temu, aby dostrzegały te problemy i je rozwiązywały". Rozwijająca się coraz bardziej idea społeczeństwa obywatelskiego, a więc samoorganizującego się, stwarza takie nadzieje i wyzwala dobrowolną aktywność społeczną w tworzeniu niezależnych od państwa różnych struktur społecznych (Wnuk-Lipiński, 2005), podejmujących się trudu zreorganizowania podejścia i wypracowania postaw społecznych wobec zachowań i zjawisk dotyczących problemów społecznych, w tym reintegracji społecznej skazanych w warunkach środowiska otwartego.

Warunkiem skutecznej realizacji koncepcji reorganizacji społecznej w rozwiązywaniu problemów społecznych zarówno w wymiarze lokalnym, jak i krajowym jest wykreowanie odpowiedniego przywództwa jednostkowego lub grupowego, które mogłoby się podjąć kształtowania nowego wymiaru postaw w społecznościach, tj. eliminacji postaw stygmatyzujących, piętnujących, wykluczających, a które znaczna część społeczeństwa posiada, w zamian za kształtowanie świadomości społecznej o tej kategorii osób marginalizowanych, którzy są częścią społeczeństwa, czyli nas samych.

Należy wziąć pod uwagę budowanie wokół ludzi z marginesu społecznego obywatelskiego ruchu wsparcia, utworzonego przez osoby gotowe pracować z nimi i rozpoznawać ich potrzeby, potencjał i możliwości powrotu do normalnego życia. Tu na uwagę zasługuje idea samoorganizowania się byłych skazanych, którzy nie otrzymując należytej pomocy od rodziny, środowiska lokalnego, struktur samorządowych, mają poczucie odrzucenia, ekskluzji społecznej i szukają we własnych grupach pomocy, szczególnie u tych, którym udało pozostać w społeczeństwie, choć tak naprawdę są gdzieś na uboczu.

Istniejące rozproszone grupy działające na rzecz reintegracji społecznej skazanych powstały z potrzeby sytuacji, brakuje im jednak pomocy profesjonalistów i osób, które mogłyby wspierać ideę byłych więźniów w warunkach środowiska otwartego. Często postrzegane są negatywnie i borykają się z brakiem zrozumienia społecznego dla ich działań na rzecz poprawy sytuacji odrzuconych. Natomiast podjęcie trwałej współpracy z tymi grupami (określanymi jako fundacje, stowarzyszenia) stwarza podstawy do budowania reintegracyjnego lub inkluzyjnego ruchu społecznego czy nowego podsystemu społecznego, działającego na rzecz skazanego i społeczeństwa oraz prospołecznych postaw wobec problemów ludzkich. 
W procesie reorganizowania się postaw społeczeństwa związanych z readaptacją i reintegracją społeczną znaczącą rolę odgrywają media (Ambrozik, 2010), szczególnie gdy są odpowiednio przygotowane i świadome swojej misji. Rozwijanie kontaktów społeczeństwa z byłymi więźniami, rozumienie ich potrzeb stanowi istotę integracji socjalnej, zaś realizowanie określonych zadań, wykonywanie pracy, podejmowanie wspólnych działań jest zaletą integracji funkcjonalnej. Z perspektywy społeczno-etycznej równe szanse dla każdego członka społeczeństwa są prawem, nie przywilejem, reintegracja daje możliwość zmiany nastawień społecznych w stosunku do tego typu osób. Z punktu widzenia prawno-ustawodawczego ten aspekt wpisany jest w system prawny i gwarantuje (zakłada gwarancję pomocy) pomoc w różnym stopniu, w większości przypadków zbyt skąpą, podobnie jak w zakresie pomocy psychologicznej.

Występujące bariery społeczne, związane z prezentowanymi negatywnymi postawami społeczeństwa, powodują znaczne ograniczenia w życiu społecznym, w aktywności i w pełnieniu różnych ról społecznych oraz w podejmowaniu zadań zawodowych w grupie pracowników niewykwalifikowanych. Bariery kulturowe wiążą się z negatywnym nastawieniem społeczeństwa do osób, które przebywały w zakładach karnych. Opinie na temat przestępców są zdecydowanie powszechne i mimo że przebywają oni na wolności, to przez członków społeczeństwa odbierani są krytycznie. Reintegracja jest zatem szansą na mądre partnerstwo obu stron i podnoszenie efektywności działań w środowisku w stosunku do tych osób i ich rodzin. System integracyjny zapobiega procesom instytucjonalizacji, daje możliwość pełnego uczestnictwa wszystkim w życiu społecznym i budowania solidarności społecznej poprzez akceptację drugiego człowieka.

Ideą zaś inkluzji jest przygotowanie społeczeństwa od najmłodszych lat do znajomości problemu i rozwijania świadomości społecznej poprzez różne formy edukacji w przedszkolu, w szkole, w zakładach pracy, a także edukacji otoczenia w kierunku wykształcenia zachowań prospołecznych i umiejętności życia społecznego z różnymi grupami społecznymi, w którym respektowane są prawa każdego człowieka. Resocjalizacja oparta na zasadach inkluzji zakłada prawo do błędów i trudności, które nie zostaną rozwiązane przez penalizację, lecz wskazują na zmianę w podejściu do stylu pracy, sposobów oddziaływania, indywidualnego wsparcia i postępowania wobec jednostki. To przede wszystkim akceptowanie różnorodności w sensie potencjału człowieka, jego problemów i szans na wspólne życie w środowisku (Konopczyński, 2006). Zachowań destrukcyjnych, demoralizujących zdecydowanie nie należy popierać, jednak akceptacja człowieka jako jednostki i podmiotu wymaga zrozumienia i przyjęcia w środowisku 
lokalnym. Inkluzja skupia się na skutkach wykluczenia społecznego i rozpatruje człowieka indywidualnie jako osobę i jego sytuację życiową w danej sytuacji.

W Raporcie Komisji Europejskiej inkluzję określa się jako proces stwarzający osobom zagrożonym ubóstwem i wykluczeniem społecznym możliwość uzyskania szans i zasobów potrzebnych do pełnego uczestnictwa w życiu ekonomicznym, społecznym i kulturalnym oraz osiągnięcia poziomu życia i dobrostanu traktowanych jako normalne w danym społeczeństwie. Inkluzja zapewnia lepszy udział tych osób w procesach podejmowania decyzji dotyczących ich życia i lepszy dostęp do ich podstawowych praw (Szatur-Jaworska, 2005). Wobec takiego stanowiska pojawiają się wątpliwości co do realności założeń inkluzji, bowiem należałoby zadowolić się sukcesem rozumianym jako „wprzęgniecie ludzi marginalizowanych w reguły i rytm jakiejś zorganizowanej ludzkiej aktywności i/lub zakorzenienie ich w jakiejś strukturze pośredniczącej miedzy nimi i otwartym społeczeństwem" (Grotowska-Leder, Faliszek, 2005, s. 49), co może nastręczać wiele problemów, m.in. w poszukiwaniu autorytetów, które podniosłyby ten problem i ukazały w świetle wielkiego wyzwania i powinności społecznej (np. Marek Kotański czy Jurek Owsiak).

Istotnym zagadnieniem w procesie przeciwdziałania ekskluzji osób niepełnosprawnych, marginalizowanych, w tym ludzi starych, jest rozwijanie idei edukacji inkluzyjnej, ukierunkowanej na zdobycie wykształcenia i miejsce na rynku pracy, ale również na edukację społeczeństwa w zakresie przeciwdziałania wykluczeniu społecznemu tychże grup społecznych, które z powodu braku sprawności, innych deficytów lub stygmatyzacji nie mogą znaleźć miejsca w środowisku społecznym. Inkluzja nie jest stanem stałym, jest to ciągły proces zmian, który dotyczy budowania społeczności w różnych obszarach: szkoły, środowiska lokalnego, zakładu pracy i rozbudowania infrastruktury na potrzeby zarówno osób marginalizowanych, jak i całego społeczeństwa. W inkluzji chodzi o zaspokajanie potrzeb osoby nieprzystosowanej, wykluczonej kosztem innych osób w życiu społecznym poprzez określone działania wobec tej osoby. Inkluzja będzie tu przełamywaniem barier między byłym skazanym a społeczeństwem, podejmowaniem współpracy w życiu społecznym na rzecz wspólnego celu, wspierania rozwoju każdego człowieka i stwarzania możliwości jego samorealizacji, co w konsekwencji będzie korzyścią dla jednostki i dla całego społeczeństwa. Jednym z celów wychowania inkluzyjnego jest stworzenie warunków do uruchomienia samodzielnych motywacji (Pytka, 2010), choćby jako forma „pomoc dla samopomocy”, czasem praktykowanej jako praca dla ogółu w ekstremalnych warunkach.

Rozwiązania systemowe koncepcji prowadzą do zaprzeczenia ekskluzji poprzez akceptację tych osób, zrozumienie aż do przyjęcia i włączenia w życie 
społeczne na poziomie indywidualnej dojrzałości. Warto podkreślić, że w koncepcji inkluzji nadal mają miejsce podmiotowość i autonomia wychowanka, tak wyraźnie podkreślane przez Czesława Czapówa (1978), wzbogacone o nowe aspekty wolności i użyteczności w sensie jednostkowym i grupowym, równości szans, integracji, samorealizacji i tożsamości jednostki. Wzmacnianie pozytywnych form zachowania może odbywać się poprzez stwarzanie warunków zewnętrznych i wewnętrznych, uodparniających ludzi na zachowania patologiczne i dewiacje (przy opanowanych umiejętnościach „przesiąkania nimi”) w środowisku naturalnym, przy udziale skoordynowanej polityki reintegracyjnej państwa, wszelkich organizacji, stowarzyszeń i Kościoła (Pytka, 2012), a także spójnych oddziaływań wychowawczych w rodzinie i szkole oraz w środowisku lokalnym czy też we wzajemnej pomocy lokalnej. Ten proces przystosowywania się jednostki lub grupy do funkcjonowania w zmienionym (lub nowym) środowisku, polega na nieustannej interakcji zachodzącej między jednostką (lub grupą) a środowiskiem, w wyniku której dochodzi do przekształcania wewnętrznej struktury podmiotu oraz sposobów działania zgodnie z wymaganiami otoczenia, a także do przekształcania otoczenia i dopasowywania go do struktury wewnętrznej. Przekształcenie sposobów działania jednostki lub grupy może wynikać właśnie z „przemiany wewnętrznej” lub oznaczać zewnętrzne dostosowanie się do zmienionych warunków działania, nie naruszając w istotny sposób dotychczasowego kształtu struktury wewnętrznej podmiotu. Obie możliwości, tzn. zmiana zachowania wynikająca ze zmiany wartości i poglądów oraz instrumentalna zmiana zachowań przy utrzymaniu dotychczasowych wartości i przekonań, wyznaczają dwa krańce kontinuum adaptacji społecznej, w tym również readaptacji społecznej jako ponownego przystosowania jednostki będącej w izolacji do pełnego samodzielnego, aktywnego i wartościowego życia według warunków i zasad społeczno-moralnych panujących w środowisku lokalnym. Readaptacja ma na celu przygotowanie skazanych do ich odpowiedzialnego życia w społeczeństwie, wypracowania poprawnych form spędzania czasu wolnego, przeciwdziałania patologiom społecznym, kształtowania u skazanych umiejętności pozwalających na pełnienie akceptowanych ról społecznych oraz przeciwdziałanie poczuciu wykluczenia i potępienia przez społeczeństwo.

W polskim systemie penitencjarnym środki oddziaływania na skazanych, takie jak praca, zdobywanie kwalifikacji zawodowych, nauczanie, zajęcia kulturalno-oświatowe i sportowe, podtrzymywanie kontaktów z rodziną i światem zewnętrznym oraz procedury terapeutyczne, można określić mianem metod readaptacji społecznej skazanych. Obejmują także różnego rodzaju działania profilaktyczne, np. profilaktykę uzależnień, profilaktykę stosowania agresji i przemocy domowej, a także inne różnorodne metody oddziaływań 
wychowawczych i resocjalizacyjnych (Szczygieł, 2002, s. 64). H. Machel (2004) wskazuje na czynniki determinujące pomyślność readaptacji społecznej skazanych, mającej miejsce w środowisku otwartym. Podkreśla, że brak odpowiedniej kontroli i wsparcia społecznego (dozór kuratora, zdolność readaptacyjna, społeczeństwa), pomocy społecznej, nazywanej postpenitencjarną, powoduje powrót na drogę przestępczą wśród osób karanych. Pomoc społeczna i wsparcie społeczne są bowiem niezbędne dla procesu readaptacji społecznej. Pomoc społeczna dotyczy zarówno więźniów, jak i ich rodzin. Dla rodziny jest to przede wszystkim pomoc w przyjęciu zwolnionego z zakładu karnego członka rodziny (poprzez mediacje rodzinne), natomiast dla skazanego jest to pomoc w znalezieniu pracy, miejsca zamieszkania, pomoc w nauce, w załatwieniu spraw urzędowych. Ustawa z dnia 6 czerwca 1997 r. Kodeks karny wykonawczy, art. 164 i 165, wskazuje na okres do 6 miesięcy przed przewidywanym terminem opuszczenia zakładu karnego mający na celu przygotowanie skazanych do życia na wolności. Przede wszystkim chodzi o nawiązanie kontaktu z kuratorem sądowym i innymi podmiotami zajmującymi się pomocą skazanym w powrocie do społeczeństwa. Czas pobytu w zakładzie karnym powinien być wykorzystany do zmian korekcyjnych w osobowości skazanego i - co ważne - by ten okres nie był zmarnowany, a służył poprawie. Moment przyjęcia do zakładu karnego mógłby być momentem rozpoczęcia przygotowań do opuszczenia więzienia. Ludzie po długotrwałym i intensywnym treningu niemożności decydowania o sobie oraz o swoich sprawach, z których zdjęto odpowiedzialność za siebie, tracą lata życia i umiejętność radzenia sobie w nowych sytuacjach, gdzie nie wystarczy więzienny spryt, ale konieczne jest działanie niestereotypowe i kreatywne (Matysiak-Blaszczyk, 2003, s. 77).

Irena Dybalska (2000) wyróżnia trudności adaptacyjne skazanych po powrocie do warunków wolnościowych. Są to problemy związane z samodzielnym funkcjonowaniem, zadbaniem o pożywienie, schronienie, pracę. Skazani przeżywają także trudności w relacjach interpersonalnych, w nawiązaniu nowych kontaktów i tym bardziej w odnowieniu relacji międzyosobowych, przede wszystkim z rodziną i najbliższymi. Bardzo trudno jest powrócić na wolność osobom starszym. Wracając do społeczeństwa otwartego, muszą oni rozpoznać na nowo obowiązujące tam prawa i obyczaje, które znacząco różnią się od reguł życia więziennego i uległy zmianie podczas nieobecności skazanego w środowisku lokalnym. Proces readaptacji społecznej zainicjowany jest podczas wykonywania kary pozbawienia wolności (Ambrozik, 2007); kary, która ma zapobiec powrotowi do przestępstwa poprzez wzbudzenie w skazanym woli współdziałania w kształtowaniu jego społecznie pożądanych postaw, poczucia odpowiedzialności oraz potrzeby przestrzegania porządku prawnego 
(art. 67 k.k.w.), daje też skazanemu prawo do swobodnego kształtowania swego postępowania, proponując mu pomoc w zmianie postaw. Skazany zatem może wykorzystać czas pobytu w zakładzie karnym na uczenie się ról społecznie pożądanych i zaspokojenie swoich potrzeb oraz korzystanie z praw, respektując prawa innych członków społeczeństwa. U podstaw readaptacji społecznej muszą się znaleźć założenia wskazujące na to, że każde przestępstwo jest wynikiem niesprzyjających warunków tkwiących w środowisku lokalnym (Ambrozik, 2010) i powinno być zlikwidowane (przezwyciężone) w tych warunkach, w których miało miejsce (Czapska, 1999).

Readaptację traktuje się jako końcową fazę procesu resocjalizacji, która finalizuje się po opuszczeniu zakładu karnego w konkretnym środowisku skazanego, dlatego najważniejszym zadaniem dla pomyślnej readaptacji jest objęcie opieką i wsparciem ze strony tego środowiska i struktur społecznych w nim funkcjonujących. Działania readaptacyjne powinny być skierowane na odbudowanie relacji rodzinnych i sąsiedzkich, zdobycie pracy i utrzymanie zatrudnienia, zamieszkania z rodziną lub znalezienia schronienia. Proces readaptacji byłego skazanego jest wyznaczony nowymi formami zachowania, w którym dodatkową trudność wyznaczają nowe reguły postępowania, zmiany społeczne i gospodarcze, które nastąpiły w środowisku pod jego nieobecność. Dla przebiegu procesu readaptacji społecznej, zwłaszcza w przypadku osób odbywających kary długoterminowe, są to zmiany, które towarzyszą rozwojowi każdego społeczeństwa. Zdarzają się też radykalne zmiany, takie jak przemiany ustrojowe o charakterze lokalnym czy regionalnym, powodujące rozwój bądź załamanie się lokalnego rynku pracy, obniżanie się dochodów ludności. Są to zjawiska typowe dla polskiej rzeczywistości, które wydają się utrudniać lub uniemożliwiać readaptację społeczną skazanych (Ambrozik, 2010).

Wydaje się, że zmiany społeczne procesu transformacji, jakie dokonują się w wielu sferach życia, zmierzają w kierunku społeczeństwa anonimowego (Urban, 2004, s. 151), obojętnego na sytuacje innych i unikającego odpowiedzialności za drugiego człowieka będącego w trudnej sytuacji życiowej. Należy zrobić wszystko, aby zmiany strukturalne transformującego się społeczeństwa i państwa zmierzały w kierunku demokracji normatywnej, gwarantującej spójność wartości i norm. Jednak na razie mamy do czynienia z brakiem spójności między systemem państwa a regułami życia społecznego i działalnością całego systemu państwa a regułami życia społecznego, a także działalnością całego systemu opieki i wychowania, w tym systemu pomocy postpenitencjarnej. Jeśli dokonamy bilansu czynników leżących po stronie jednostki, jej kompetencji i nastawień, jak i po stronie społeczności, do której wraca eks-dewiant, 
sprzyjających społecznej readaptacji i skutecznie ją blokujących, to z całą pewnością wynik tego porównania nie wypadnie pomyślnie.

Zdarzają się przypadki udanej readaptacji społecznej, gdy edukacja podjęta podczas pobytu w zakładzie karnym, zdobyte kwalifikacje zawodowe i zadomowienie się w środowisku lokalnym przyczyniły się do poprawnego wejścia w życie społeczne. Pełnione przez jednostkę nowe role społeczne (po pewnym okresie czasu) wyznaczają jej pozycję w strukturze grupy, określają jej uprawnienia nadane przez grupę oraz obowiązki, jakie musi ona wypełnić. Ważne, aby w procesie resocjalizacji i readaptacji społecznej uwzględnić potrzeby, zainteresowania i możliwości jednostki, co przyczyni się do poprawnej realizacji zadań zgodnie z kierunkiem własnego rozwoju jednostki. Readaptację społeczną należy odnieść także do systemu społecznego, który powinien się dostosować - i się dostosowuje - do specyficznych sytuacji i cech społeczno-demograficznych wykluczonych przez ten sam system.

W wielu sytuacjach, w znacznym stopniu, stwarza się sytuacje do powstawania zachowań patologicznych, dlatego w społeczeństwie nie brakuje osób bezrobotnych, bezdomnych czy przestępców. Dotychczasowe zachowania w większości przypadków mają charakter kary i eliminacji ze społeczeństwa, przeciwdziałania zagrożeniom poprzez profilaktykę w różnych grupach i kręgach społecznych oraz poprzez próby resocjalizowania w warunkach środowiska otwartego (praca kuratora w ramach nadzoru i dozoru nad podopiecznym, praca socjalna) lub w warunkach izolacji więziennej.

Propozycje resocjalizacji wielowymiarowej z udziałem całego społeczeństwa (Bałandynowicz, 2011) wydają się optymalnym rozwiązaniem, jednak wymagają przygotowania do tego przedsięwzięcia. W pierwszej kolejności powinny nastąpić zmiany polityki społecznej z „restrykcyjno-stygmatyzującej”, mającej charakter wykluczania człowieka ze społeczności, w kierunku polityki reintegracji społecznej, realizowanej zgodnie z propozycjami inkluzyjności, a więc realnej pomocy i wsparcia społecznego.

Zdecydowanie więcej występuje negatywnych przykładów readaptacji społecznej, które wskazują na pilną potrzebę podejmowania stosownych wyzwań społecznych. Dobrą ilustracją tej sytuacji są przytoczone poniżej osobiste doświadczenia jednego ze skazanych.

System niszczy wszystko. System, z którym tak dzielnie każdego dnia stawałem do boju, dziś bierze na mnie odwet. Przecież z więzień wypuszczają zwierzęta. Przecież my nie jesteśmy przygotowani do niczego. Nikt nie myśli, co będzie z nami po wyjściu. Zostawiają nas samym sobie. Ale jak ma sobie radzić oślepione ciemnością zwierzę, wypuszczone w słoneczny dzień? Jak? Kto mu założy szmatę 
na oczy, by mogło powoli przyzwyczaić się do normalności? Kto nie będzie się bał? Nie będzie oceniał? Kto pokona obrzydzenie, niechęć? Nie ma takich śmiałków. A jeżeli już znajdzie się tak silna i zdeterminowana osoba, to niestety pozostaje jeszcze jeden poziom do pokonania - chęć drugiej strony. Potrzeba dużo czasu i przede wszystkim dużo szczęścia, by przejść to piekło, jakim jest poczekalnia do wolności. Jak wielu ludzi musi w tym uczestniczyć? Jak wielu z nich doświadcza bólu, zniechęcenia po spotkaniu z takim czymś jak ja? (Sikora, Gruca, 2009, s. 297).

Edukacja inkluzyjna odnosi się do nabywania świadomości i umiejętności potrzebnych do wzięcia odpowiedzialności za swoje życiowe szanse. Jest to zwiększenie możliwości jednostek i grup w podejmowaniu własnych decyzji i w większym niż dotychczas zakresie w kształtowaniu swojego przeznaczenia, czyli kolektywne życie bez prześladowania i wyzysku.

\section{MIEJSCE CZŁOWIEKA \\ W INKLUZYJNO-KATALAKTYCZNYM MODELU REINTEGRACJI SPOŁECZNEJ}

W modelu inkluzyjno-kataktycznym postanowiono odwołać się do najnowszych trendów w literaturze psychopedagogicznej, uwzględniając interdyscyplinarne podejście systemowe, którego celem jest poprawa systemów społecznego wsparcia dzięki działaniom środowiskowym, włączanie wykluczonych do społeczeństwa przy ich aktywnym udziale, posiadanych zasobach i potencjale, kształtowanie świadomości i wzmacnianie kompetencji społeczeństwa (Kieszkowska, 2012). Za podstawę modelu przyjęto wielopasmową teorię resocjalizacji A. Bałandynowicza, założenia edukacji inkluzyjnej, teorię katalaktyki F. Hayeka oraz teorię równowagi interpersonalnej Z. Zaborowskiego. W celu wzmocnienia działań społecznych i zmiany tożsamości skazanych w programie reintegracji społecznej wskazane jest wykorzystanie koncepcji uspołecznienia systemu profilaktyki i resocjalizacji W. Ambrozika oraz koncepcji twórczej resocjalizacji M. Konopczyńskiego. Działania reintegracyjne, w tym również samopomocowe, mają na celu odbudowanie i podtrzymywanie umiejętności uczestniczenia w życiu społeczności lokalnej oraz przyjęcie nowych akceptowanych ról społecznych w miejscu pracy, zamieszkania lub pobytu na zasadzie wymiany dóbr materialnych i niematerialnych (Kieszkowska, 2011).

Wymiana społeczna oparta na odpowiedzialności za drugiego człowieka, zaufaniu, prawie do wyboru i zaciągania zobowiązań stanowi szansę dla 
wykluczonych społecznie w odnajdywaniu własnych zasobów i potencjału w warunkach środowiska otwartego. W myśl catallaxy bycie członkiem społeczeństwa oznacza nie tylko ekonomiczną wymianę poprzez wytwarzanie określonych dóbr, lecz także przyjmowanie do społeczności jako pełnoprawnego obywatela i podejmowanie ważnych i odpowiedzialnych zadań w społeczności.

Program reintegracyjny powinien być zatem dostosowany do indywidualnych potrzeb i możliwości skazanego na podstawie przeprowadzonej wcześniej diagnozy psychopedagogicznej i wiedzy zawartej w dokumentacji skazanego oraz warunków środowiskowych, w których będzie przebywał skazany. Działania inkluzyjno-katalaktyczne projektowane w stosunku do jednostki i grupy, utrwalane w miejscu zamieszkania i wspierane przez specjalistów, rodzinę, społeczeństwo i media mogą przyczynić się do wypracowania optymalnych sposobów radzenia sobie w sytuacjach trudnych i właściwego rozumienia lokalnego powrotu skazanych. Realizacja takiego programu powinna odbywać się w środowisku lokalnym skazanego (praca indywidualna lub w małych grupach), aby w pierwszej kolejności wypracować umiejętności przystosowania się do wykonywania podstawowych zadań i obowiązków. Treningi prowadzone pod kierunkiem asystenta probacyjnego, instruktora zawodu czy pracownika socjalnego mogą się przyczynić do opanowania krok po kroku określonych czynności, zrozumienia sensu podejmowanych zadań oraz satysfakcji z poprawnie wykonywanej pracy.

Pozwoli to również na wnikliwe poznanie zachowań podopiecznego i projektowanie indywidualnych działań wyrównujących deficyty w określonych obszarach funkcjonowania oraz stopniowania trudności. Wieloletnie badania dotyczące przystosowania się skazanych wpisują się w projektowany model i wskazują na dynamikę zmian zachodzących w procesie reintegracji, co przyczyni się bezpośrednio w pracy terapeutycznej ze skazanymi do uwzględnienia zmian w ich zachowaniu i stosowania indywidualnych metod pracy. Proces reintegracji skazanych obejmuje udział jednostki, grupy i społeczeństwa w ponownej integracji tych osób.

Ukierunkowane działania powinny uwzględniać ocenę sytuacji życiowej jednostek o różnym potencjale, sile i miejscu życiowym, możliwość ich wykorzystania w racjonalny sposób dla rozwoju osobowego, społecznego i kulturowego. Potencjał życiowy, siła życiowa, miejsce życiowe oraz zasoby jednostek są niekwestionowanym kapitałem społecznym, jeżeli osoby otrzymają należyte wsparcie dla ich rozwijania. Rolę w procesie powrotu do społeczeństwa powinny spełniać wszystkie instytucje i organizacje działające na rzecz pomocy drugiemu człowiekowi, a kurator, oficer probacyjny czy asystent miałby szansę odpowiedniego prowadzenia programu reintegracji w warunkach wolnościowych, 
w bezpośrednich relacjach z osobami wymagającymi ukierunkowania, analizowania ich osiągnięć na poszczególnych etapach programu.

W programie reintegracji społecznej należy zaplanować działania inkluzyjno-katalaktyczne dostosowane do indywidualnych potrzeb byłych podopiecznych, ich rodzin i środowiska lokalnego, mające na celu nie tylko włączenie do społeczności, lecz także wymianę międzyosobową opartą na systemie wartości, a także wymianę ekonomiczną, której podstawą są wzajemne działania jednych wobec drugich.

Konieczne będzie, w ramach diagnozy psychopedagogicznej i obserwacji zachowań skazanych, poszukiwanie u nich korzystnych zasobów osobistych, takich jak wsparcie społeczne, poczucie własnej skuteczności i wartości, optymizm, poczucie kontroli, ekspresja emocji, doświadczenia z radzeniem sobie w trudnych sytuacjach, konstruktywne sposoby radzenia sobie ze stresem, zdrowy tryb życia, racjonalne myślenie, duchowość - wiara, zaangażowanie, motywacja, orientacja prospołeczna, poczucie koherencji (zrozumiałość, sterowalność, sensowność - poczucie wartości życia), wola życia, mechanizmy obronne, jakość zaspokajania potrzeb psychospołecznych, zainteresowania, wiedza i doświadczenia zawodowe, status socjoekonomiczny. Zasoby te mają nieocenione znaczenie dla każdej jednostki w konfrontacji $\mathrm{z}$ otaczającą rzeczywistością i są wyznacznikiem jakości życia człowieka.

W procesie usamodzielniania się skazanego istotną rolę spełniają także inne osoby, których wiarygodność i zaangażowanie w odkrywaniu właściwej drogi w procesie terapii będą szansą na odbudowanie w przyszłości poprawnych relacji osobowych i społecznych. Terapia psychologiczna połączona z innymi formami leczenia (m.in. uzależnień), z uwzględnieniem potrzeb jednostkowych, jest gwarantem zrozumienia aktualnej sytuacji skazanego i oczekiwań społecznych wobec niego. Umiejętna edukacja w zakresie występujących deficytów może wprowadzić skazanego na wyższy poziom kompetencji i samooceny. Wskazywanie możliwości osiągania zdolności przystosowawczych bez konieczności łamania norm prawa jest wyzwaniem dla jednostki i jej samorealizacji.

Wymienione obszary mają zastosowanie tylko wtedy, gdy jednostka w warunkach wolnościowych ma permanentne wsparcie ze strony specjalistów w trakcie trwania programu reintegracji społecznej w modelu inkluzyjno-katalaktycznym, gdy są sprzyjające warunki dla podnoszenia się na wyższy poziom osób marginalizowanych w obszarach środowiska lokalnego, gospodarki, społeczeństwa i jego kultury. Wtedy rozumienie lokalnego powrotu jednostki do równowagi społecznej będzie uzasadnione aktualnymi potrzebami społecznymi.

Wydaje się, że trudno określić czas terapii dla skazanych powracających do środowiska lokalnego. Jednak na podstawie obserwacji innych grup mających 
za sobą stany traumatyczne wiadomo, że nie może on trwać krócej niż rok, a maksymalnie do dwóch lat - w zależności od okresu izolacji penitencjarnej i jej skutków. Może natomiast być połączony (lub powinien) z wyrównywaniem deficytów społecznych i pozycji byłego skazanego w grupie społecznej, zawodowej. Realizacja na nowo zadań zawodowych powinna mieć charakter instruktażu (w zależności od stopnia umiejętności zawodowych i występujących braków w tym zakresie) i powinna odbywać się w przystosowanych do tego typu pracy stanowiskach (warsztatach), aby w przyszłości były skazany mógł realizować te lub podobne zadania w zespole innych pracowników i znał zasady technologii oraz tempa pracy. Właściwe przygotowanie zawodowe stanowi również w tym przypadku podstawę odpowiedzialnego podejmowania zadań w zakładzie pracy. Brak kompetencji rodzi obawy, lęk i niechęć do wykonywania powierzanych zadań, tym bardziej wtedy, gdy te zadania będą podejmowane ponownie na wolności po dłuższej przerwie i w nowych (innych) warunkach.

Udział rodziny, grupy i społeczeństwa powinien sprzyjać reintegracji społecznej byłych skazanych. Osoby z otoczenia rodzinnego, społecznego i zawodowego powinny być świadome swojej roli w motywowaniu skazanego do pracy oraz prezentowania określonej postawy społecznej i zawodowej, otwartości, odpowiedzialności i współdziałania w tym procesie inkluzji.

Szczególną misję do spełnienia w programie reintegracji społecznej należy przypisać mediom, których zadaniem jest właściwe wskazywanie zaangażowania byłych skazanych w poprawę swojej sytuacji, odnajdywanie się na nowo w rolach społecznych i w społeczeństwie oraz wyróżnianie zakładów pracy stawiających na różnorodność, wspólną wymianę dóbr i usług służących społeczeństwu. Proponowane obszary pracy reintegracyjnej miałyby szansę realizacji w sytuacji pełnego zaangażowania wielu podmiotów i reorganizacji polityki kryminalnej i penitencjarnej oraz świadomego udziału społeczeństwa. Dla przyjętych w modelu działań inkluzyjno-katalaktycznych ważne staje się przygotowanie skazanego do usamodzielnienia się w procesie reintegracji społecznej i wdrażanie ich w warunkach środowiska otwartego. Proces probacji skazanych ma zwiększać szansę ich skutecznej reintegracji poprzez lepsze przystosowanie do życia w społeczeństwie.

Na potrzeby badań (Kieszkowska, 2012) założono, że w procesie inkluzji, na obecnym etapie funkcjonowania społeczeństwa, można uwzględnić takie działania, jak pomoc w identyfikacji ryzyka (socjalna, pedagogiczna, psychologiczna, medyczna, prawna); opieka psychopedagogiczna, medyczna i prawna, poradnictwo zawodowe (doskonalenie, przekwalifikowanie); interwencja kryzysowa; pomoc w edukacji; wsparcie ze strony określonych grup samopomocowych; pomoc w uzyskaniu i utrzymaniu pracy; wsparcie ze strony 
kuratorów probacyjnych o charakterze edukacyjnym, konsultacyjnym; wsparcie i edukacja rodzin osób uwięzionych oraz informowanie i przygotowanie środowiska lokalnego do przyjmowania do społeczności ,innego".

W zakresie wymiany spolecznej (katalaktyka) istotne będzie: odpowiedzialne pełnienie ról społecznych; pełnienie ról rodzinnych i dobre relacje z rodziną; poprawne kontakty sąsiedzkie i towarzyskie; udział w życiu wspólnoty; działalność w organizacjach i stowarzyszeniach; prace na cele charytatywne i użyteczności publicznej: przedsięwzięcia w środowisku lokalnym.

Wyrównywanie szans z kolei powinno się uwidaczniać $\mathrm{w}$ określonych zachowaniach byłych skazanych i ich postrzeganiu otaczającej rzeczywistości, poprzez: brak konfliktów z prawem; ograniczenie, wyeliminowanie kontaktów z grupami marginalizowanymi; możliwość zaspokojenia potrzeb psychospołecznych na właściwym poziomie; stabilizacja psychiczna (pozytywna samoocena, radzenie sobie w sytuacjach trudnych, konstruktywne rozwiązywanie konfliktów, poczucie sensu życia, plany życiowe, dyspozycyjny optymizm, poczucie własnej skuteczności i wiara w zakładane cele).

Proponowany model uwzględnia fakt, że były skazany i środowisko powinni tworzyć wzajemną sieć powiązań na różnych etapach reintegracji społecznej. Samodzielne spłacanie długu ofiarom przestępstwa lub ich rodzinom, praca na rzecz społeczeństwa i w społeczeństwie przyczyniają się do prawidłowego rozwoju jednostki i kształtowania odpowiedzialności za swoje czyny oraz los społeczeństwa.

\section{WNIOSKI}

Wprowadzanie programów readaptacyjnych do niedawna budziło pewne obawy i wiązało się z brakiem umiejętności ich realizacji. Po pewnym czasie - przynajmniej w przekonaniu pracowników placówek penitencjarnych - nastąpiło jednak większe zrozumienie oraz motywacja do wdrażania tych programów, ale nadal powstaje dużo różnych inicjatyw, które w warunkach wolnościowych nie dadzą się zweryfikować pozytywnie. Byli więźniowie nie mają bowiem żadnych umiejętności, a ich sfera psychiczna jest bardzo zaniedbana i wykorzystują jedynie prymitywne, brutalne zachowania nabyte lub „udoskonalane” w zakładach karnych.

Jest prawdopodobne, że w niedalekiej przyszłości osoby wykluczone, ale powracające do społeczeństwa, będą mogły mieć poczucie wolności i odpowiedzialności za podejmowane działania. Jeżeli inkluzja stwarza szansę człowiekowi i społeczeństwu na realizowanie swoich zamierzeń i planów poprzez samodzielny udział i możliwość samorealizacji, to inkluzyjne wychowanie 
resocjalizacyjne, realizując określone cele, stwarza warunki do uruchomienia samodzielnych motywacji, wynikających z naturalnego potencjału rozwojowego każdego człowieka, do czego powinien zmierzać każdy wychowawca w pracy z podopiecznym (Czapów, 1978). Umożliwia też pobudzenie procesu internalizacji wartości prospołecznych poprzez uczestnictwo w konstruktywnych rolach społecznych. Cały system wychowania jest zorientowany na dostosowanie się do niej i do wszystkich jego uczestników, co pozwala zrzucić z siebie stygmat dewianta. Taki kierunek działań prowadzi do optymalnego uspołecznienia podopiecznych na miarę możliwości, zdolności i motywacji do podejmowania zadań życiowych w zakresie inkluzji społecznej.

\section{BIBLIOGRAFIA}

Ambrozik, W. (2007). Readaptacja społeczna i reorganizacja środowisk lokalnych jako warunek skuteczności oddziaływań resocjalizacyjnych. W: B. URban, J.M. StaniK (red.), Resocjalizacja. Teoria i praktyka pedagogiczna (t. 2). Warszawa: Wydawnictwo Naukowe PWN.

Aмвrozik, W. (2010). Reorganizacja społeczności lokalnej a reintegracja społeczna byłych przestępców. W: A. KieszKowsKa (red.), Tożsamość osobowa dewiantów a ich reintegracja społeczna (cz. 1). Kraków: Oficyna Wydawnicza „Impuls”.

BaŁandynowicz, A. (2011). Reintegracja społeczna skazanych. Paradygmat tożsamości osobowej, społecznej i kulturowo-cywilizacyjnej. Resocjalizacja Polska, 2, 25-52.

Benson, M.L. (2001). Crime and the Life Course. In introduction. Cincinnati, OH: University of Cincinnati.

Czapów, Cz. (1978). Wychowanie resocjalizujące. Elementy metodyki i diagnostyki. Warszawa: PWN.

Czapska, J. (1999). Zapobieganie przestępczości w społecznościach lokalnych. Możliwości i granice. W: J. CZAPSKA, W. KRUPIARZ (red.), Zapobieganie przestępczości w spolecznościach lokalnych. Warszawa: Instytut Spraw Publicznych.

Dybalska, I. (2000). Pomoc skazanym w reintegracji ze środowiskiem otwartym w polskim systemie penitencjarnym. Stan aktualny - regulacje prawne i praktyka. W: J. GóRnIEwICZ, H. KęDzierska (red.), Systemowa pomoc rodzinie $w$ procesie resocjalizacji i readaptacji społecznej. Olsztyn: Wydawnictwo UWM.

Dүксік, W. (2001). Problemy autonomii integracji społecznej i normalizacji osób niepetnosprawnych w środowisku. W: W. Dүксік (red.), Pedagogika specjalna. Poznań: Wydawnictwo UAM.

FARrington, D.P. (1992). Explaining the Beginning, Progress and Ending of Antisocial Behavior from Birth to Adulthood. W: J. McCord (red.), Facts and Forecast. London: New Bronswick.

Grotowska-Leder, J., FALISZEK, K. (2005). Ekskluzja i inkluzja - dwie strony tego samego problemu? Diagnoza - uwarunkowania - kierunki działań. Toruń: Wydawnictwo Edukacyjne Akapit.

Grzegorczyk, A. (1979). Filozofia czasu próby. Paris: Éditions du Dialoque. 
Hulek, A. (red.) (1992). Świat ludziom niepetnosprawnym. Międzynarodowy Rok (1981) i Dekada Narodów Zjednoczonych (1983-1992) Inwalidów i Osób Niepetnosprawnych. Warszawa: Polskie Towarzystwo Walki z Kalectwem.

Hurrelmann, K. (1994). Struktura społeczna a rozwój osobowości. Wprowadzenie do teorii socjalizacji. Poznań: Wydawnictwo UAM.

Kieszkowska, A. (2011). Tożsamość i podmiotowość jednostki w procesie reintegracji spotecznej. W: A. KieszKowska (red.), Tożsamość osobowa dewiantów a ich reintegracja społeczna (cz. 1). Kraków: Oficyna Wydawnicza „Impuls”.

Kieszkowska, A. (2012). Inkluzyjno-katalaktyczny model reintegracji społecznej skazanych. Konteksty resocjalizacyjne. Kraków: Oficyna Wydawnicza „Impuls”.

Konopczyński, M. (2006). Metody twórczej resocjalizacji. Teoria i praktyka wychowawcza. Warszawa: Wydawnictwo Naukowe PWN.

Kowalski, S. (1977). Przedmowa. W: J. WŁodarek (red.), System wychowawczy zaktadu poprawczego. Socjologiczne studium instytucji resocjalizacyjnej. Warszawa: Wydawnictwo Prawnicze.

Landecker, W.S., Werner, S. (1951). Types of Integration and Their Measurement. American Journal of Sociology, 56 (4), 332-340.

Machel, H. (2004). Resocjalizacja penitencjarna. Współczesny casus polski. W: K. INDECKI (red.), Aktualne problemy prawa karnego, kryminologii i penitencjarystki. Ksiega ofiarowana prof. S. Lelentalowi w 45. roku pracy naukowej i dydaktycznej (s. 241-242). Łódź: Wydawnictwo UŁ.

Matysiak-BŁaszczyk, A. (2003). Readaptacja i reintegracja społeczna opuszczających zakłady karne. W: K. Marzec-Holka (red.), Pomoc społeczna. Teoria i praktyka. Bydgoszcz: Wydawnictwo AB im. K. Wielkiego.

Modrzewski, J. (2004). Socjalizacja i uczestnictwo społeczne. Studium socjopedagogiczne. Poznań: Wydawnictwo Naukowe UAM.

Pytka, L. (2012). Readaptacja jako element polityki reintegracji społecznej. W: L. PүтKA, B.M. Nowak (red.), Problemy współczesnej resocjalizacji. Warszawa: Wydawnictwo Pedagogium.

Rylke, H. (2002). Systemowe podejście do profilaktyki. Problemy Opiekuńczo-Wychowawcze, $5,3-8$.

Shneider, H.J. (1997-1998). Przyczyny przestępczości. Nowe aspekty międzynarodowej dyskusji o teoriach kryminologicznych. Archiwum Kryminologii, 23-24, 13-44.

Sikora, S., Gruca, R. (2009). Osadzony. Poznań: Wydawnictwo Albatros.

Szatur-Jaworska, B. (2005). Diagnozowanie w polityce spolecznej. Materiaty do studiowania. Warszawa: Oficyna Wydawnicza ASPRA-JR.

Urban, B. (2004). Wzmacnianie procesu destygmatyzacji eks-dewianta jako warunek readaptacji społecznej. Rocznik Komisji Nauk Pedagogicznych, 57, 145-155.

Wnuk-Lipiński, E. (2005). Socjologia życia społecznego. Warszawa: Wydawnictwo Naukowe „Scholar”. 


\section{MOŻLIWOŚCI PRACY Z OSOBAMI WYKLUCZONYMI SPOŁECZNIE W INKLUZYJNO-KATALAKTYCZNYM MODELU W PROCESIE REINTEGRACJI SPOŁECZNEJ}

\section{Streszczenie}

Za zintegrowany można uznać ten system społeczny, w którym cele wyznaczane przez daną kulturę są w pełni akceptowane przez jednostki i osiągane za pomocą społecznie uznanych, zinstytucjonalizowanych środków z uwzględnieniem pracy określonych grup specjalistów. Wysoki poziom integracji społecznej charakteryzuje się intensywnością kontaktów między członkami danej zbiorowości, układem trwałych więzi społecznych spajających jednostki i grupy oraz ukształtowaną świadomością identyfikacji i łączności między nimi. Programy profilaktyczne, readaptacyjne, reintegracyjne lub doskonalące funkcjonowanie systemu społecznego dla określonej grupy czy środowiska społecznego powinny wychodzić od najniższego poziomu, czyli konkretnych osób uwikłanych w problemy społeczne i społeczeństwa, aby zmienić ich sposób myślenia i wartościowania, wzajemnego funkcjonowania i uczestnictwa w danym systemie. Przekształcenie sposobów działania jednostki lub grupy może wynikać z przemiany wewnętrznej lub oznaczać zewnętrzne dostosowanie się do zmienionych warunków działania, nie naruszając w istotny sposób dotychczasowego kształtu struktury wewnętrznej podmiotu. Obie możliwości, tzn. zmiana zachowania wynikająca ze zmiany wartości i poglądów oraz instrumentalna zmiana zachowań przy utrzymaniu dotychczasowych wartości i przekonań, wyznaczają dwa krańce kontinuum adaptacji społecznej, w tym również readaptacji społecznej jako ponownego przystosowania jednostki będącej w izolacji do pełnego samodzielnego, aktywnego i wartościowego życia według warunków i zasad społeczno-moralnych panujących w środowisku lokalnym. Działania reintegracyjne, w tym również samopomocowe, mają na celu odbudowanie i podtrzymywanie umiejętności uczestniczenia w życiu społeczności lokalnej i przyjęciu nowych, akceptowanych ról społecznych w miejscu pracy, zamieszkania lub pobytu na zasadzie wymiany dóbr materialnych i niematerialnych. Wymiana społeczna oparta na odpowiedzialności za drugiego człowieka, zaufaniu, prawie do wyboru i zaciągania zobowiązań stanowi szansę dla wykluczonych społecznie w odnajdywaniu własnych zasobów i potencjałów w warunkach środowiska otwartego. W myśl catallaxy bycie członkiem społeczeństwa oznacza nie tylko ekonomiczną wymianę poprzez wytwarzanie określonych dóbr, ale także przyjmowanie do społeczności jako pełnoprawnego obywatela i podejmowanie ważnych i odpowiedzialnych zadań w społeczności.

Słowa kluczowe: wyrównywanie szans; wymiana społeczna - katalaktyka; reintegracja społeczna; inkluzja społeczna; koncepcja reorganizacji społecznej.

\section{POSSIBILITIES FOR PEOPLE WITH SOCIAL DISABILITIES}

\section{Summary}

Entering re-adaptation programs until recently aroused some concerns and lack of skills of their implementation, which after some time, at least in the belief that prison staff raises greater understanding and motivation to implement. It is likely that in the near future, those who are excluded, and returning to society, they can have a sense of freedom, the responsibility for their actions. Prevention programs, readaptation, reintegration or improving the functioning 
of the social system for a specific group or social environment should Reaching-you generously from the lowest level, or individuals involved in social issues and society to change their way of thinking and evaluating, mutual functioning and participation in a given system. The transformation of modes of action of individuals or groups may result from the transformation of the inner or outer mean to adapt to changing conditions without affecting significantly the current shape of the internal structure of the entity. Both options, ie. Change in behavior resulting from changes in the values and beliefs and the instrumental behavior change while maintaining the existing values and provi-Konan nominate two ends of a continuum of social adaptation, including social reintegration as a readjustment in the entity being in isolation to fully autonomous, active and valuable life according to the terms and conditions of socio-moral prevailing in the local environment. Reintegration activities, including self-help, they have to build and maintain skills for participation in the local community and the adoption of new acceptable social roles in the workplace, residence or domicile in an exchange of tangible and intangible. Exchange-based social responsibility for another human being, trust, the right to choose and commit represents an opportunity for socially excluded people in finding their own resources and potentials within the open environmental conditions. In thought catalaxy being a member of society means not only economic exchange through the production of certain goods, but also accepting the community as a full citizen and make important and responsible tasks in the community.

Key words: equal opportunities; social exchange - catalysis; social reintegration; social inclusion; the concept of social reorganization. 